\title{
Azoxystrobin Rate and Timing Effects on Rice Sheath Blight Incidence and Severity and Rice Grain and Milling Yields
}

\author{
D. E. Groth, Professor, Rice Research Station, Louisiana Agricultural Experiment Station, LSU Agricultural Center, \\ 1373 Caffey Road, Rayne, LA 70578
}

\begin{abstract}
Groth, D. E. 2005. Azoxystrobin rate and timing effects on rice sheath blight incidence and severity and rice grain and milling yields. Plant Dis. 89:1171-1174.

Lack of sheath blight resistant varieties requires rice (Oryza sativa) farmers to use fungicides to avoid significant reductions in grain yield and milling yield. Studies were conducted to determine the best rate and rice growth stage for a single application of azoxystrobin, a fungicide recently labeled for this use, to effectively control sheath blight. Azoxystrobin was applied foliarly to inoculated field plots in 2000 to 2002 using rates of $0.22,0.17$, and $0.11 \mathrm{~kg}^{2}$ a.i. ha ${ }^{-1}$ at 7 days after panicle differentiation (PD+7), boot (B), and heading $(\mathrm{H})$ growth stages and at $0.17 \mathrm{~kg}$ a.i. ha ${ }^{-1}$ at 5,10 , and 15 days after heading. Sheath blight severity (measured on a 0 to 9 scale) and incidence (percent tillers infected) were assessed 1 to 2 weeks before harvest. A fungicide application made between PD+7 and $\mathrm{H}$ significantly reduced sheath blight severity, which resulted in significantly higher yield and head rice milling yield compared with inoculated unsprayed plots. There were no significant effects of fungicide rate at the $\mathrm{PD}+7, \mathrm{~B}$, and $\mathrm{H}$ growth stages. Fungicide-treated plots had yield and milling yield similar to the very lightly diseased, uninoculated check plots included for comparison. With fungicide application made postheading, rice had higher disease severity, resulting in lower yields and milling yield compared with rice receiving earlier applications.
\end{abstract}

Additional keywords: application timing, Rhizoctonia solani, yield loss

Sheath blight occurs in rice (Oryza sativa L.) worldwide (19). The causal organism is the basidiomycete Thanatephorus cucumeris (A.B. Frank) Donk. It is more commonly known by its imperfect stage, Rhizoctonia solani Kühn, which has been placed in the anastomosis group AG 1-IA (20). Under favorable conditions, it is the most important rice disease in the southern United States and possibly second only to blast (Pyricularia oryzae) worldwide (15). High sheath blight intensity has been attributed to modern rice production with the use of semidwarf varieties, high nitrogen fertilization, and high plant populations (7,22).

In the United States, disease severity is higher in the humid Gulf Coast growing region than in the more arid Mississippi Delta production area (7). Losses in crop production ranging from 1 to $50 \%$ occur, and are dependent on inoculum amount, crop growth stage at infection, environmental conditions, varietal resistance, and cultural management $(2,10,17,18)$. Losses occur by reductions in yield and grain

Corresponding author: D. E. Groth

E-mail: dgroth@agcenter.lsu.edu

Accepted for publication 8 June 2005.

DOI: 10.1094/PD-89-1171

(C) 2005 The American Phytopathological Society quality, and by lodging, in the first (main) crop, and in yield reductions in the second (ratoon) crop (9). Azoxystrobin, trifloxystrobin, and flutolanil were recently labeled in the United States for rice sheath blight control. While these fungicides are more effective than propiconazole and fungicides that are no longer labeled for this use in the United States, including benomyl and iprodione $(8,9,12,14)$, they can be expensive and ineffective if applied at the wrong time. Benefits from these fungicides include reduced disease development and subsequent inoculum production, and increased grain and milling yields, a key component in grain quality and price. An application of propiconazole around the boot growth stage has been shown to result in more sheath blight late in the season due to rapid disease development after fungicide activity was lost (23). It was suggested that a reduction in the potential antagonist epiphytic populations due to the fungicide's broadspectrum activity allowed disease to develop late in the season. Azoxystrobin is the most commonly used rice fungicide in the southern United States. Information is limited on the optimum rates and times of fungicide application for sheath blight control $(4,8)$. Preliminary studies suggest that the rate of azoxystrobin needed to effectively control sheath blight changes as the season progresses (9). Typical sheath blight fungicide timing is at the boot growth stage. However, azoxystrobin also controls blast when applied at heading. Consequently, there has been a general trend to apply azoxystrobin later in the season to control both blast and sheath blight with a single application. In addition, the heading growth stage is often misidentified, resulting in delayed applications. The effects of postheading applications on sheath blight control have not been studied.

The objective of this study was to determine the proper rates and timing of an azoxystrobin application to maximize sheath blight control, grain yield, and milling yield.

\section{MATERIALS AND METHODS}

Experiments were conducted at the LSU Agricultural Center's Rice Research Station in Crowley, LA. Plots were drillseeded with the sheath blight susceptible variety 'Cocodrie' (16) on 23, 22, and 18 March in 2000, 2001, and 2002, respectively, at the rate of $136 \mathrm{~kg} \mathrm{ha}^{-1}$. Plots were 1.2 by $4.9 \mathrm{~m}$, consisting of seven rows at $18-\mathrm{cm}$ spacing. Soil type was a Crowley silt loam (pH 6.0, clay $12 \%$, silt $71 \%$, sand $17 \%$, CEC $9.4 / \mathrm{kg}$ ). Fertilizer was incorporated at the rate of $20-60-60 \mathrm{~kg} \mathrm{ha}^{-1}$ of $\mathrm{N}$ P-K 1 day before planting. Agronomic, weed, and insect management practices followed current standard recommendations (1). Plots were fertilized preflood at the rate of $133 \mathrm{~kg} \mathrm{~N} \mathrm{ha}^{-1}$ as urea at the three- to four-leaf stage and postflood at the rate of $24 \mathrm{~kg} \mathrm{~N} \mathrm{ha}^{-1}$ as ammonium sulfate at the beginning of stem internode elongation (green ring).

Inoculation. To obtain uniform disease development, plots were inoculated at the late tillering growth stage with a virulent isolate of $R$. solani (LR172) isolated from a naturally infected rice plant (cv. Lebonnet) in Louisiana in 1972 by M. C. Rush. Inoculum was produced on a moist autoclaved rice grain/rice hull mixture (1:2 $\mathrm{vol} / \mathrm{vol}$ ) incubated in the dark for 12 to 14 days at $30^{\circ} \mathrm{C}$. The grain-hull inoculum was broken into small (1- to 4-mm-diameter) particles, consisting of several rice grains held together by fungal mycelia. Approximately $100 \mathrm{ml}\left(17 \mathrm{ml} \mathrm{m}^{-2}\right)$ was distributed evenly over each plot by hand, except for the uninoculated controls, on 22, 24, and 25 May 2000, 2001, and 2002, respectively.

Fungicide treatments. Azoxystrobin (Quadris 2.08 SC; Syngenta, Raleigh, NC) 
was applied once at $0,0.11,0.17$, or 0.22 $\mathrm{kg}$ a.i. $\mathrm{ha}^{-1}$, which are the most common rates used commercially, 7 days after panicle differentiation (panicle $2.5 \mathrm{~mm}$ ) (PD+7), boot (5 to $10 \mathrm{~cm}$ panicle in the boot) (B), and heading (50 to $70 \%$ of heads emerging from the boot) $(\mathrm{H})$. Additional treatments included $0.17 \mathrm{~kg}$ a.i. azoxystrobin per ha applied $5(\mathrm{H}+5), 10$ $(\mathrm{H}+10)$, and $15(\mathrm{H}+15)$ days after heading. Treatments were applied at a delivery rate of 140 liters $\mathrm{ha}^{-1}$ with a $\mathrm{CO}_{2}$ backpack sprayer. Dates of applications were PD+7: 7 June 2000, 30 May 2001, and 3 June 2002; B: 15 June 2000, 7 June 2001, and 8 June 2002; H: 22 June 2000, 15 June 2001, and 13 June 2002; H+5: 27 June 2000, 20 June 2001, and 17 June 2002; H+10: 3 July 2000, 25 June 2001, and 21 June 2002; and H+15: 7 July 2000, 29 June 2001, and 26 June 2002. Uninoculated unsprayed (light natural infection) and inoculated unsprayed (severe disease similar to severely affected commercial fields not treated with fungicides) checks were included for comparison.

Disease assessments and yield determination. Plots were evaluated for sheath blight development approximately 1 week before maturity and assigned severity ratings using a semi-quantitative linear scale $(9,12,15,23)$ on 17,19 , and 15 July 2000 , 2001, and 2002, respectively. The ratings were: $0=$ plants healthy, no symptoms; $1=$ restricted dark brown oval lesions at waterline or infection points; 2 = few oval or coalesced lesions with broad borders on lower sheaths or at infection points, $5 \%$ or less of tissue affected; $3=$ lesions on lower leaf sheaths or at infection points, lesions coalescing, less than $10 \%$ of tissues affected; 4 = lesions mainly restricted to sheaths on lower third of plant, lowest leaves, or other infection points, lesions discrete or coalescing with narrow red-brown border, 10 to $15 \%$ of leaf and sheath tissues affected; $5=$ lesions mainly restricted to sheaths and leaves of lower half of plants, lesions usually coalescing with large necrotic centers and narrow redbrown borders, 15 to $25 \%$ of tissues affected; $6=$ lesions usually coalescing and affecting lower two-thirds of sheath area of plant, lesions extending to blades of lower leaves or lower leaves killed by injury to sheath, 25 to $40 \%$ of tissues affected; 7 = lesions usually coalescing and affecting lower three-fourths of sheath area of plant, lesions extending to leaf blades of lower two-thirds of plant, 40 to $60 \%$ of tissues affected; $8=$ lesions reaching to flag leaf, lower sheaths with coalesced lesions covering most of tissue, lower and middle leaves dead or dying, 60 to $80 \%$ of tissues affected; and $9=$ lesions reaching to flag leaf, lower leaves mostly dead, sheaths dried, culms brown, collapsing, most tillers lodged, over $80 \%$ of tissue affected. At the same time, 25 tillers at four locations in the center four rows of each plot were examined for symptoms, and percent symptomatic tillers were calculated.

On 26, 25, and 22 July 2000, 2001, and 2002 , respectively, the center four rows of each plot were harvested with a small plot rice combine. Grain yield and moisture were determined, and rice yields adjusted to $12 \mathrm{~g} \mathrm{~kg}^{-1}$ moisture were determined. A 125 -g grain subsample was collected from each harvest sample for determining milling percentages of whole (unbroken kernels) and total rice (broken and whole grains). The subsample was hulled with a McGill Sheller, setting 19 (RAPSCO, Brookshire, TX) to remove the lemma and palea. The resulting brown rice was then processed in a McGill Miller (RAPSCO) for $30 \mathrm{~s}$ to remove the bran layers and part of the embryo. The milled sample was weighed to determine total milled yield percentages and then placed on a Grainman grain separator (Grain Machinery Manufacturing Corporation, Miami, FL) with no. 10 then no. 11 plates to remove broken kernels. Whole kernels were then weighed to determine whole milling or head rice. Milling yield percentages were calculated as [(weight/125)*100]. Head rice milling yield was considered commercially acceptable if it met the standard industry values for rice of $55 \%$ head rice and $70 \%$ total rice.

Data analysis. Treatments were replicated four times and arranged in a randomized complete block design with a new randomization each year. Statistical analyses were performed using mixed models $F$ tests, and when significant $(P=0.05)$ treatment effects were found, orthogonal contrasts were constructed to compare treatment means in each factor. An LSD was calculated for each variable for means comparisons. Statistical analyses were conducted using SAS version 8.2 (SAS Institute, Cary, NC).

\section{RESULTS}

Disease development and effect of azoxystrobin treatments. In plots inoculated with $R$. solani, initial symptoms developed on 10 to $20 \%$ of the tillers within 7 to 10 days of inoculation. No other yield reducing disease developed. These infestation levels were within treatment thresholds for sheath blight $(1,11)$. Uninoculated plots were relatively disease free. Severe sheath blight developed uniformly each year but was significantly lower in 2002. Year by treatment effects were not significant $(P=0.05)$. Percent tillers affected by sheath blight ranged from $6 \%$ in the uninoculated unsprayed check to $78 \%$ in the inoculated unsprayed check (Table 1). All fungicide treatments had significantly fewer tillers infected than the inoculated unsprayed check except the $\mathrm{H}+10$ and $\mathrm{H}+15$ applications. Comparing treatments with different fungicide rates applied to rice at $\mathrm{PD}+7, \mathrm{~B}$, and $\mathrm{H}$ revealed no signifi-

Table 1. Effects of time and rate of azoxystrobin application on sheath blight incidence and severity, yield, and milling yield ${ }^{\text {a }}$

\begin{tabular}{|c|c|c|c|c|c|c|c|}
\hline \multirow[b]{2}{*}{ Treatment } & \multirow{2}{*}{$\begin{array}{c}\text { Application } \\
\text { time } \\
\text { (growth stage) }\end{array}$} & \multirow{2}{*}{$\begin{array}{c}\text { Fungicide } \\
\text { rate } \\
\left(\mathrm{kg} \text { a.i. } \text { ha }^{-1}\right)\end{array}$} & \multirow{2}{*}{$\begin{array}{c}\text { Infected }^{\mathrm{c}} \\
\text { tillers } \\
(\%)\end{array}$} & \multirow{2}{*}{$\begin{array}{c}\text { Sheath blight }^{\mathrm{d}} \\
\text { severity } \\
(0-9)\end{array}$} & \multirow{2}{*}{$\begin{array}{c}\text { Grain } \\
\text { yield } \\
\left(\mathbf{k g ~ h a}^{-1}\right)\end{array}$} & \multicolumn{2}{|c|}{ Milling yield } \\
\hline & & & & & & $\begin{array}{c}\text { Head rice } \\
(\%)\end{array}$ & $\begin{array}{c}\text { Total } \\
(\%)\end{array}$ \\
\hline Uninoculated unsprayed & $\ldots$ & $\ldots$ & 6 & 3.3 & 9,628 & 63.4 & 71.2 \\
\hline Inoculated unsprayed & $\ldots$ & $\ldots$ & 78 & 7.7 & 7,136 & 59.1 & 70.0 \\
\hline Azoxystrobin & $\mathrm{PD}+7$ & 0.22 & 15 & 3.6 & 9,983 & 63.3 & 71.1 \\
\hline Azoxystrobin & $\mathrm{PD}+7$ & 0.17 & 12 & 3.6 & 9,458 & 62.4 & 70.7 \\
\hline Azoxystrobin & $\mathrm{PD}+7$ & 0.11 & 27 & 4.8 & 9,398 & 62.9 & 71.1 \\
\hline Azoxystrobin & Boot & 0.22 & 16 & 3.9 & 9,312 & 62.7 & 71.1 \\
\hline Azoxystrobin & Boot & 0.17 & 15 & 4.1 & 9,192 & 62.9 & 71.0 \\
\hline Azoxystrobin & Boot & 0.11 & 12 & 3.9 & 9,311 & 63.2 & 71.1 \\
\hline Azoxystrobin & Heading & 0.22 & 34 & 5.0 & 9,294 & 62.6 & 70.7 \\
\hline Azoxystrobin & Heading & 0.17 & 30 & 4.3 & 9,102 & 62.8 & 70.7 \\
\hline Azoxystrobin & Heading & 0.11 & 28 & 4.2 & 9,245 & 62.4 & 70.7 \\
\hline Azoxystrobin & Heading +5 & 0.17 & 49 & 5.7 & 8,390 & 61.8 & 70.4 \\
\hline Azoxystrobin & Heading+10 & 0.17 & 61 & 6.4 & 8,080 & 60.6 & 69.7 \\
\hline Azoxystrobin & Heading+15 & 0.17 & 65 & 6.9 & 7,701 & 60.3 & 69.8 \\
\hline $\operatorname{LSD}(P=0.05)$ & & & 17 & 1.0 & 465 & 1.2 & 0.7 \\
\hline
\end{tabular}

a Means are 3-year average of small plot field tests conducted at the Rice Research Station, Crowley, LA, 2000 to 2002.

b Timings used were PD+7 ( 7 days after panicle differentiation or panicle $2 \mathrm{~mm}$ in size), boot ( 5 to $10 \mathrm{~cm}$ panicle in the boot), heading ( 70 to $80 \%$ of panicles emerging), and Heading $+5,+10,+15$ (5, 10, and 15 days after heading, respectively).

c Percent tillers infected with sheath blight at approximately 1 week before harvest.

d Sheath blight rated 1 week before harvest on a 0 to 9 scale where $0=$ no disease and $9=$ plants dead and collapsed. 
cant differences in percent tillers infected, but average severity increased as fungicide applications were delayed. Comparing treatments made at $0.17 \mathrm{~kg}$ a.i. $\mathrm{ha}^{-1}$ revealed that average incidence increased as fungicide applications were delayed with post-H applications having significantly higher percent tillers infected than at $\mathrm{PD}+7, \mathrm{~B}$, and $\mathrm{H}$.

Sheath blight severity in naturally infested plots was very low, rating 3.3 in the uninoculated check. Severe sheath blight, averaging 7.7, developed in the inoculated unsprayed check. All treatments had significantly lower sheath blight severity than the inoculated unsprayed check except $\mathrm{H}+15$. Fungicide rate, compared at $\mathrm{PD}+7$, $\mathrm{B}$, and $\mathrm{H}$, did not significantly affect sheath blight severity. When comparing the $0.17 \mathrm{~kg}$ a.i. $\mathrm{ha}^{-1}$ rate, average severity increased as fungicide applications were delayed with post-H applications having significantly higher sheath blight ratings than at $\mathrm{PD}+7, \mathrm{~B}$, and $\mathrm{H}$.

Grain yield and quality. Again, year by treatment effects were not significant $(P=$ $0.05)$, and results are presented as 3-year averages. The uninoculated check yielded 2,492 $\mathrm{kg} \mathrm{ha}^{-1}$ more than the inoculated check (Table 1). Yield was as much as 2,847 $\mathrm{kg} \mathrm{ha}^{-1}$ higher than the inoculated unsprayed check for rice treated at PD+7, $\mathrm{B}$, and $\mathrm{H}$. Fungicide rate did not significantly affect yield for applications made at $\mathrm{PD}+7, \mathrm{~B}$, or H. Compared with rice treated with $0.17 \mathrm{~kg}$ a.i. ha ${ }^{-1}$ azoxystrobin at $\mathrm{H}$, average yield was $712,1,022$, and $1,401 \mathrm{~kg}$ $\mathrm{ha}^{-1}$ lower when the fungicide application was delayed 5, 10, and 15 days, respectively, after $\mathrm{H}$.

Head rice milling yield was commercially acceptable (standard industry values for rice are at least $55 \%$ head rice and $70 \%$ total rice) in all treatments. All fungicide treatments had significantly higher whole grain milling yield than the inoculated unsprayed check (Table 1). Compared to rice treated with $0.17 \mathrm{~kg}$ a.i. $\mathrm{ha}^{-1}$ azoxystrobin at $\mathrm{H}$, there was a significant reduction in whole grain milling yield when the fungicide application was delayed 10 and 15 days after $H$. Fungicide rate did not significantly affect milling yield for applications at $\mathrm{PD}+7, \mathrm{~B}$, or $\mathrm{H}$ growth stages.

Total milling yield was higher in the uninoculated unsprayed check than in the inoculated unsprayed check. Applying azoxystrobin at the $\mathrm{PD}+7, \mathrm{~B}$, or $\mathrm{H}$ growth stage increased total milling yield equally compared with the inoculated check. Fungicide rate did not significantly affect total milling yield. Total milling yield was reduced by delaying fungicide applications after $\mathrm{H}$.

\section{DISCUSSION}

Percent affected tillers and severity of sheath blight from natural inoculum was very low in these experiments, but sheath blight caused significant yield and milling yield reductions to rice plants in inoculated unsprayed plots compared with rice in uninoculated plots. The difference between the lightly diseased uninoculated control and the inoculated unsprayed control indicated that sheath blight can cause a $22 \%$ grain yield loss with an additional 4.3 percentage point reduction in whole grain milling yield on the cultivar Cocodrie. These reductions are very important to the economic return a rice producer would receive from his crop. Under current economic conditions, this loss is over \$450/ha. These disease levels and yield reductions are very comparable to previous studies conducted in small plots and commercial fields $(9,11,17)$.

Sheath blight was very effectively controlled with azoxystrobin applied once at $\mathrm{PD}+7, \mathrm{~B}, \mathrm{H}$, and to a lesser extent at $\mathrm{H}+5$ growth stages. Control ranged from 89 to $56 \%$ reduction in tillers infected at PD+7 to $\mathrm{H}$ and $38 \%$ at $\mathrm{H}+5$ to only 17 to $22 \%$ control at $\mathrm{H}+10$ to $\mathrm{H}+15$ growth stages. Fungicide rate did not significantly affect disease development or yield response for applications made at the $\mathrm{B}$ or $\mathrm{H}$ growth stages. However, higher rates were required at PD+7 to get maximum control because lower rates did not suppress late season disease development. The cost of using the lowest rate tested, \$31.12/ha based on the 2005 price for azoxystrobin, represents a substantial savings over the cost of using the highest rate tested, $\$ 62.24 /$ ha. Applying azoxystrobin at the lowest labeled rate, $\$ 46.68 /$ ha, also represents a meaningful savings for farmers. Postheading fungicide applications were less effective than applications made earlier due to sheath blight infecting more tillers and progressing up the plant further, which resulted in lower grain yield and milling yield. Delaying fungicide application could also result in introduction of more inoculum into the field as infested rice stubble that could affect subsequent crops. Early applications at any rate did not lead to higher sheath blight disease levels as reported by Van Eeckhout et al. in 1992 (23). In their study, the fungicide propiconazole was used, which is inherently not as effective as azoxystrobin against sheath blight.

An application of azoxystrobin fungicide at $\mathrm{PD}+7, \mathrm{~B}$, or $\mathrm{H}$ growth stages reduced sheath blight severity and incidence, which produced better rice yield and milling yield. The sheath blight epidemic was initiated each year at approximately the same growth stage that the epidemic normally starts to develop in commercial fields. Preliminary studies indicated that sheath blight development as early as internode formation and as late as the boot split growth stage causes similar yield and quality losses, and fungicide applied at $\mathrm{PD}+7, \mathrm{~B}$, and $\mathrm{H}$ can prevent most of these losses $(5,6)$. It is not surprising that late season disease development causes this much damage, because sheath blight usu- ally does not develop rapidly until rice enters its reproductive growth stages $(21,22)$. This would also explain why postheading fungicide applications did not protect yield and grain quality: because sheath blight rapidly infected more tillers and moved higher up the plant before the fungicide was applied.

Fungicide applications have been commonly used in South Louisiana rice production $(3,9)$. In the past, two fungicide treatments were often needed to effectively control sheath blight (23), but with the labeling of higher activity fungicides and economic constraints that limit the number of applications, a single application approach is now the most common scenario. This study showed that good control was possible with a single application of azoxystrobin made at an appropriate growth stage. Currently, the U.S. label for azoxystrobin formulated as Quadris only recommends lower rates if disease does not develop until heading and if applied to moderately resistant cultivars. This study suggests that lower rates earlier in the season are beneficial but a higher rate may be needed to maximize benefits. However, waiting to apply fungicide until after heading can allow sheath blight to develop to a point that the application cannot prevent significant yield and milling losses.

Farmers often delay fungicide applications for sheath blight control until heading to also target blast. In other studies, late fungicide applications (after $\mathrm{H}$ ) also result in reduced blast control and resulting yield increases in the same way as late sheath blight applications $(5,6)$. A small shift of a few days can make a great difference in rice yield and quality. Farmers in Louisiana are now encouraged to monitor growth stages as they scout for diseases to maximize returns from fungicide applications.

The results from these studies are based on a susceptible cultivar grown in small plots. Caution generally is recommended when extrapolating small plot data to field situations. Trends demonstrated in small plot research typically translate into field situations $(8,13)$. This is especially true when multiple tests are conducted over several years. Yield increases due to fungicide applications and levels of disease development were similar between the Rice Research Station (inoculated plots) and off-station locations (natural infestations in commercial fields) $(5,6)$. Aerial trials conducted in commercial fields in Louisiana have had similar results to small plot tests (13).

This study demonstrated that farmers can control sheath blight and improve rice yield and milling by applying azoxystrobin once at PD+7, B, or H. Rates of $0.11,0.17$, and $0.22 \mathrm{~kg}$ a.i. ha ${ }^{-1}$ were equally effective at these application timings. Lower than labeled rates can be legally used without special labeling, but nonperformance complaints may not be supported by agricul- 
tural companies. Applications after $\mathrm{H}$ were not as effective as these earlier application times.

\section{ACKNOWLEDGMENTS}

I thank Clayton Hollier, Richard Dunand, and Jeff Hoy for reviewing this manuscript and giving many helpful suggestions. I also thank the Louisiana Rice Research Board and Syngenta for providing support for this research and publication. I thank Marty Frey and Joe Nugent for their hard work and assistance in conducting these studies.

\section{LITERATURE CITED}

1. Anonymous. 1999. Louisiana Rice Production Handbook. LSU Agricultural Center. Pub. No. 2321, Revised.

2. Gangopadhyay, S., and Chakrabarti, N. K. 1982. Sheath blight of rice. Rev. Plant Pathol. 61:451-460.

3. Giesler, G. G., Heagler, A. M., and Groth, D. E. 1994. Economic analysis of fungicide use in rice production. La. Agric. 37:20-22.

4. Groth, D. E. 1996. Two new fungicides to control rice diseases. La. Agric. 39:31-33.

5. Groth, D. E., Frey, M. J., and Nugent, J. 2002. Rice disease control studies, 2001. Annu. Res. Rep., Rice Res. Stn., La. Agric. Exp. Stn., LSU Agricultural Center 93:313-369.

6. Groth, D. E., Frey, M. J., and Nugent, J. 2003. Rice disease control studies, 2002. Annu. Res. Rep., Rice Res. Stn., La. Agric. Exp. Stn., LSU Agricultural Center 94:254-300.
7. Groth, D., and Lee, F. 2003. Rice diseases. Pages 413-436 in: Rice Origin, History, Technology, and Production. C. W. Smith and R. H. Dilday, eds. John Wiley \& Sons, Hoboken, NJ

8. Groth, D. E., and Rush, M. C. 1988. New fungicides to control sheath blight of rice. La. Agric. 31:8-9.

9. Groth, D. E., Rush, M. C., Giesler, G. G., and Hollier, C. A. 1993. Foliar fungicides for use in the management of rice diseases. La. Agric. Exp. Stn. Bull. No. 840.

10. Groth, D. E., Rush, M. C., and Hollier, C. A. 1991. Rice diseases and disorders in Louisiana. La. Agric. Exp. Stn. Bull. No. 828.

11. Groth, D. E., Rush, M. C., and Hollier, C. A. 1992. Prediction of rice sheath blight severity and yield loss based on early season infection. La. Agric. 35:20-23.

12. Groth, D. E., Rush, M. C., and Lindberg, G. D. 1990. Foliar fungicides for control of rice diseases in the United States. Pages 31-52 in: Pest Management in Rice. B. T. Grayson, M. B. Green, and L. G. Copping, eds. Elsevier Sc. Publ., London.

13. Hollier, C. A., Groth, D. E., Levy, R. J., Courville, B. A., and McCorry, J. C. 1994. Rice yield differences: A comparison of fungicide application methods. Proc. Rice Tech. Wrkg. Grp. 25:88-89.

14. Jones, R. K.., Belmar, S. B., and Jeger, M. J. 1987. Evaluation of benomyl and propiconazole for controlling sheath blight of rice caused by Rhizoctonia solani. Plant Dis. 71:222-225.
15. Lee, F. N., and Rush, M. C. 1983. Rice sheath blight: A major rice disease. Plant Dis. 67:829832.

16. Linscombe, S. D., Bollich, P. K., Groth, D. E White, L. M., and Dunand, R. T. 2000. Registration of 'Cocodrie' rice. Crop Sci. 40:294.

17. Marchetti, M. A. 1983. Potential impact of sheath blight on yield and milling quality of short statured rice lines in the southern United States. Plant Dis. 67:162-165.

18. Marchetti, M. A., and Bollich, C. N. 1991 Quantification of the relationship between sheath blight severity and yield loss in rice. Plant Dis. 75:773-775.

19. Ou, S. H. 1985. Rice Diseases, 2nd ed. Commonw. Mycological Institute, Kew, England.

20. Rush, M. C., and Lee, F. N. 1992. Sheath blight. Pages 22-23 in: Compendium of Rice Diseases. R. K. Webster and P. S. Gunnell, eds. American Phytopathological Society, St. Paul, MN.

21. Savary, S., Willocquet, L., and Teng, P. S 1997. Modeling sheath blight epidemics on rice tillers. Agric. Syst. 55:359-384.

22. Shahjahan, A. K. M., and. Mew, T. W. 1989 Analysis of rice sheath blight (Rhizoctonia solani) development under tropical condition. Bangladesh J. Plant Pathol. 5:47-52.

23. Van Eeckhout, E., Rush, M. C., and Blackwell, M. 1991. Effects of rate and timing of fungicide applications on incidence and severity of sheath blight and grain yield of rice. Plant Dis. 75:1254-1261.

\section{Erratum}

A correction to this article was made on December 8, 2005. On the last line of page 1171 , the formulation of the fungicide should read "Quadris 2.08 SC." 